\title{
Differential Visualization of Dopamine and Norepinephrine Uptake Sites in Rat Brain Using [ ${ }^{3} \mathrm{H}$ ]Mazindol Autoradiography ${ }^{1}$
}

\author{
JONATHAN A. JAVITCH, STEPHEN M. STRITTMATTER, AND SOLOMON H. SNYDER ${ }^{2}$
}

Departments of Neuroscience, Pharmacology and Experimental Therapeutics, and Psychiatry and Behavioral Sciences, The Johns Hopkins University School of Medicine, Baltimore, Maryland 21205

\begin{abstract}
Mazindol is a potent inhibitor of neuronal dopamine (DA) and norepinephrine (NE) uptake. DA and NE uptake sites in rat brain have been differentially visualized using $\left[{ }^{3} \mathrm{H}\right]$ mazindol autoradiography. At appropriate concentrations, desipramine (DMI) selectively inhibits $\left[{ }^{3} \mathrm{H}\right]$ mazindol binding to NE uptake sites without significantly affecting binding to DA uptake sites. The localization of DMI-insensitive specific $\left[{ }^{3} \mathrm{H}\right]$ mazindol binding, reflecting DA uptake sites, is densest in the caudate-putamen, the nucleus accumbens, the olfactory tubercle, the subthalamic nucleus, the ventral tegmental area, the substantia nigra (SN) pars compacta, and the anterior olfactory nuclei. In contrast, the localization of DMIsensitive specific $\left[{ }^{3} \mathrm{H}\right]$ mazindol binding, representing NE uptake sites, is densest in the locus coeruleus, the nucleus of the solitary tract, the bed nucleus of the stria terminalis, the paraventricular and periventricular nuclei of the hypothalamus, and the anteroventral thalamus. The distribution of DMIinsensitive specific $\left[{ }^{3} \mathrm{H}\right]$ mazindol binding closely parallels that of dopaminergic terminal and somatodendritic regions, while the distribution of DMI-sensitive specific $\left[{ }^{3} \mathrm{H}\right]$ mazindol binding correlates well with the regional localization of noradrenergic terminals and cell bodies. Injection of 6-hydroxydopamine, ibotenic acid, or colchicine into the SN decreases $\left[{ }^{3} \mathrm{H}\right]$ mazindol binding to DA uptake sites in the ipsilateral caudate-putamen by $85 \%$. In contrast, ibotenic acid lesions of the caudate-putamen do not reduce $\left[{ }^{3} \mathrm{H}\right]$ mazindol binding to either the ipsilateral or contralateral caudate-putamen. Thus, the DA uptake sites in the caudate-putamen are located on the presynaptic terminals of dopaminergic axons originating from the $\mathrm{SN}$.
\end{abstract}

Synaptic inactivation of the catecholamines, dopamine (DA) and norepinephrine (NE), is achieved primarily by high-affinity uptake into nerve terminals. While the DA and NE uptake processes have similar substrate specificities, a variety of evidence indicates substantial differences in the molecular structure of these complexes (Horn,

Received August 6, 1984; Revised October 25, 1984;

Accepted October 26, 1984

1 This work was supported by United States Public Health Service Grants MH-18501, and NS-16375, Research Scientist Award DA-00074 to S. H. S., Training Grant GM-07309 to J. A. J. and S. M. S., and a grant from the McKnight Foundation. We thank Naomi R. Taylor for technical assistance and Dawn C. Dodson for secretarial assistance.

${ }^{2}$ To whom correspondence should be directed, at Department of Neuroscience, The Johns Hopkins University School of Medicine, 725 North Wolfe Street, Baltimore, MD 21205.
1976; Ross, 1976). Drugs such as benztropine have somewhat greater affinity for the DA uptake site (Horn et al., 1971), whereas tricyclic antidepressants, such as desipramine (DMl), are much more potent in inhibiting NE uptake (Horn, 1973; Eckhardt et al., 1982). $\left[{ }^{3} \mathrm{H}\right] \mathrm{DM}$ labels binding sites associated with the neuronal NE uptake system in membrane homogenates prepared from brain and periphcral tissucs (Hrdina ct al., 1981; Langer et al., 1981; Lee and Snyder, 1981; Lee et al., 1982, 1983; Rehavi et al., 1982). Furthermore, in vitro autoradiography using $\left[{ }^{3} \mathrm{H}\right] \mathrm{DM}$ visualizes NE uptake sites (Biegon and Rainbow, 1983). Sodium-sensitive cocaine binding to striatal membranes may in part label DA uptake sites (Kennedy and Hanbauer, 1983), although the relatively low affinity of cocaine for the binding sites makes a detailed evaluation difficult.

Mazindol, a clinically employed appetite suppressant, potently inhibits both NE and DA uptake (Heikkila et al., 1977; Hyttel, 1982). $\left[{ }^{3} \mathrm{H}\right]$ Mazindol labeis both DA and NE uptake sites in rat brain homogenates (Javitch et al., 1983; 1984). DMl at appropriate concentrations selectively abolishes $\left[{ }^{3} \mathrm{H}\right]$ mazindol binding to NE uptake sites without significantly affecting binding to DA uptake sites (Javitch et al., 1984). In the present study, we have differentially visualized sites associated with NE and DA uptake utilizing $\left[{ }^{3} \mathrm{H}\right]$ mazindol autoradiography in the presence or absence of DMl.

\section{Materials and Methods}

$\left[{ }^{3} \mathrm{H}\right]$ Mazindol ( $11 \mathrm{Ci} / \mathrm{mmol}$ ) was supplied by New England Nuclear, Boston, MA. Sources of other drugs were as described previously (Javitch et al., 1984). Male Sprague-Dawley rats (150 to $200 \mathrm{gm}$ ) were anesthetized with pentobarbital and perfused via the left ventricle of the heart with $0.9 \% \mathrm{NaCl}$, $50 \mathrm{~mm}$ sodium phosphate, $\mathrm{pH} 7.5$, followed by $50 \mathrm{~mm}$ sodium phosphate and $0.3 \mathrm{M}$ sucrose. Brains were removed, embedded in brain paste, and rapidly frozen at $-70^{\circ} \mathrm{C}$ on microtome chucks. Sections $(8 \mu \mathrm{M})$ were cut at $-15^{\circ} \mathrm{C}$ and thaw-mounted on gelatin-coated slides. The slides were dessicated and then stored at $20^{\circ} \mathrm{C}$. For autoradiographic studies, sections were preincubated at $4^{\circ} \mathrm{C}$ for $5 \mathrm{~min}$ in $50 \mathrm{~mm}$ Tris buffer $\left(\mathrm{pH} 7.9\right.$ at $4^{\circ} \mathrm{C}$, containing $120 \mathrm{mM} \mathrm{NaCl}, 5 \mathrm{~mm} \mathrm{KCl}$ ) and then incubated for $40 \mathrm{~min}$ at $4^{\circ} \mathrm{C}$ in the assay buffer ( $50 \mathrm{~mm}$ Tris, $\mathrm{pH} 7.9$, at $4^{\circ} \mathrm{C}, 300$ or $120 \mathrm{~mm} \mathrm{NaCl}, 5 \mathrm{~mm} \mathrm{KCl}$ ) with 4 $\mathrm{nM}\left[{ }^{3} \mathrm{H}\right] \mathrm{mazindol}$ in the presence or absence of inhibitors. Nonspecific binding was determined in the presence of $1 \mu \mathrm{M}$ mazindol. DMl-sensitive specific $\left[{ }^{3} \mathrm{H}\right]$ mazindol is defined as the difference between total binding and binding in the presence of $0.3 \mu \mathrm{M}$ DMl. DMl-insensitive binding is the difference between $\left.{ }^{3} \mathrm{H}\right]$ mazindol bound in the presence of $0.3 \mu \mathrm{M} \mathrm{DMl}$ and the amount bound in the presence of $1 \mu \mathrm{m}$ unlabeled mazindol (see "Results"). After two consecutive 1-min washes in the same buffer, the slides were dipped in water and immediately dried under a stream of cold dry air. Autoradiograms were generated by apposing the slides to LKB Ultrofilm for 5 to 6 weeks at $4^{\circ} \mathrm{C}$ (Unnerstall et al., 1982). Following autoradiography, tissue was stained with $0.1 \%$ toluidine blue. Density of silver grains on Ultrofilm was quantificd by computer-assisted microdensitometry and converted to femtomoles of $\left[{ }^{3} \mathrm{H}\right]$ mazindol bound per milligram of protein (Kuhar et al., 1984).

Coronal brain sections at the level of the caudate-pularmerı were used for saturation analysis, drug inhibition, and ion concentration experiments. Total and nonspecific binding for each concentration or condition were averaged from two sections from each of two brains. Tissue sections were wiped off the slide with a Whatman GF/B glass fiber filter and counted using liquid 
scintillation spectrometry. Saturation analysis of binding used 1, 2, 6, 10, 25 and $50 \mathrm{nM}\left[{ }^{3} \mathrm{H}\right]$ mazindol. $K_{D}$ and $B_{\max }$ values were calculated from saturation binding data using an iterative curve fitting program (McPherson, 1983). Binding of $\left[{ }^{3} \mathrm{H}\right]$ mazindol to tissue homogenates was assayed as described previously (Javitch et al., 1984).

For lesion studies, $4 \mu \mathrm{g}$ of colchicine (Sigma), $15 \mu \mathrm{g}$ of ibotenic acid (Regis), or $8 \mu \mathrm{g}$ of 6-hydroxydopamine hydrobromide (6-OHDA) (Sigma) in 2 $\mu \mathrm{l}$ of $0.9 \% \mathrm{NaCl}$ were injected into the center of the left caudate-putamen or the left substantia nigra (SN) using stereotaxic coordinates measured from the interaural line. To confirm the location of the needle tip, a dye was injected into an age-matched rat, and the brain was dissected and inspected visually. Coronal sections at the level of the caudate-putamen were obtained as described above 7 to $14 \mathrm{~d}$ after the injections.

\section{Results}

Characteristics of $\beta \mathrm{H}]$ mazindol binding. To ensure that $\left[{ }^{3} \mathrm{H}\right]$ mazindol labels DA uptake sites in rat brain slices, the pharmacological properties of $\left[{ }^{3} \mathrm{H}\right]$ mazindol binding to brain slices at the level of the caudate-putamen were evaluated. The striatum contains predominantly DA uptake sites with relatively few NE uptake sites (Table If; Figs. 2 and 3 ). $\left[{ }^{3} \mathrm{H}\right]$ Mazindol binds saturably and with high affinity to striatal slices in accordance with results obtained previously using striatal homogenates (Javitch et al., 1983; 1984). Specific binding of $4 \mathrm{~nm}\left[{ }^{3} \mathrm{H}\right]$ mazindol at $300 \mathrm{~mm} \mathrm{NaCl}$ is about $70 \%$ of total binding in the caudate-putamen. Scatchard analysis reveals a single component of binding with a dissociation constant $\left(K_{D}\right)$ of $15 \mathrm{nM}$ and a maximal number of binding sites $\left(\mathrm{B}_{\text {max }}\right)$ of $7.8 \mathrm{pmol} / \mathrm{mg}$ of protein. These values agree closely with those obtained in striatal homogenates (Javitch et al., 1984) as well as with the potency of mazindol as an inhibitor of DA uptake (Hyttel, 1982). Specific $\left[{ }^{3} \mathrm{H}\right]$ mazindol binding to brain slices is dependent upon sodium with half-maximal binding at $250 \mathrm{~mm} \mathrm{NaCl}$ (Fig. 1). By contrast, potassium chloride fails to augment binding.

The conclusion that $\left[{ }^{3} \mathrm{H}\right]$ mazindol binding to striatal slices is associated with DA uptake sites is supported by the potency of various uptake inhibitors in inhibiting binding (Table I). Nomifensine and benztropine, two inhibitors of DA uptake (Hyttel, 1982), potently reduce $\left[{ }^{3} \mathrm{H}\right]$ mazindol binding to striatal slices, as does mazindol itself. By contrast, $0.3 \mu \mathrm{M} \mathrm{DMl}$, which potently inhibits NE but not DA uptake (Hyttel, 1982), has negligible effect on specific $\left[{ }^{3} \mathrm{H}\right]$ mazindol binding to striatal slices. These results confirm that binding of $\left[{ }^{3} \mathrm{H}\right]$ mazindol to striatal slices has the same properties as binding in striatal homogenates, which is associated with DA uptake sites (Javitch et al., 1983, 1984).

Comparable experiments assessing $\left[{ }^{3} \mathrm{H}\right]$ mazindol binding associated with NE uptake sites were not performed in tissue slices, since in nonstriatal parts of the brain, levels of specific $\left[{ }^{3} \mathrm{H}\right]$ mazindol binding are too low to permit accurate quantification by liquid scintillation spectrometry. However, in homogenates of the cerebral cortex with $1 \mu \mathrm{M}$ mazindol employed to define nonspecific binding, inhibition of specific $\left[{ }^{3} \mathrm{H}\right]$ mazindol binding by DMl is biphasic with a high-affinity component displaying a $\mathrm{K}_{\mathrm{i}}$ of about $10 \mathrm{nM}$ (Fig. 2). This high-affinity component reflects binding to NE uptake sites (Javitch et al., 1984). A concentration of $0.3 \mu \mathrm{M} \mathrm{DMI}$ maximally inhibits the high-affinity component of $\left[{ }^{3} \mathrm{H}\right]$ mazindol to cortical membranes without affecting the lower affinity component. In cerebral cortical homogenates, specific $\left[{ }^{3} \mathrm{H}\right]$ mazindol binding to $\mathrm{NE}$ uptake sites, assessed using $0.3 \mu \mathrm{M}$ DMl to define nonspecific binding, is saturable and displays a single component with a $K_{D}$ of about $4 \mathrm{~nm}$ and a

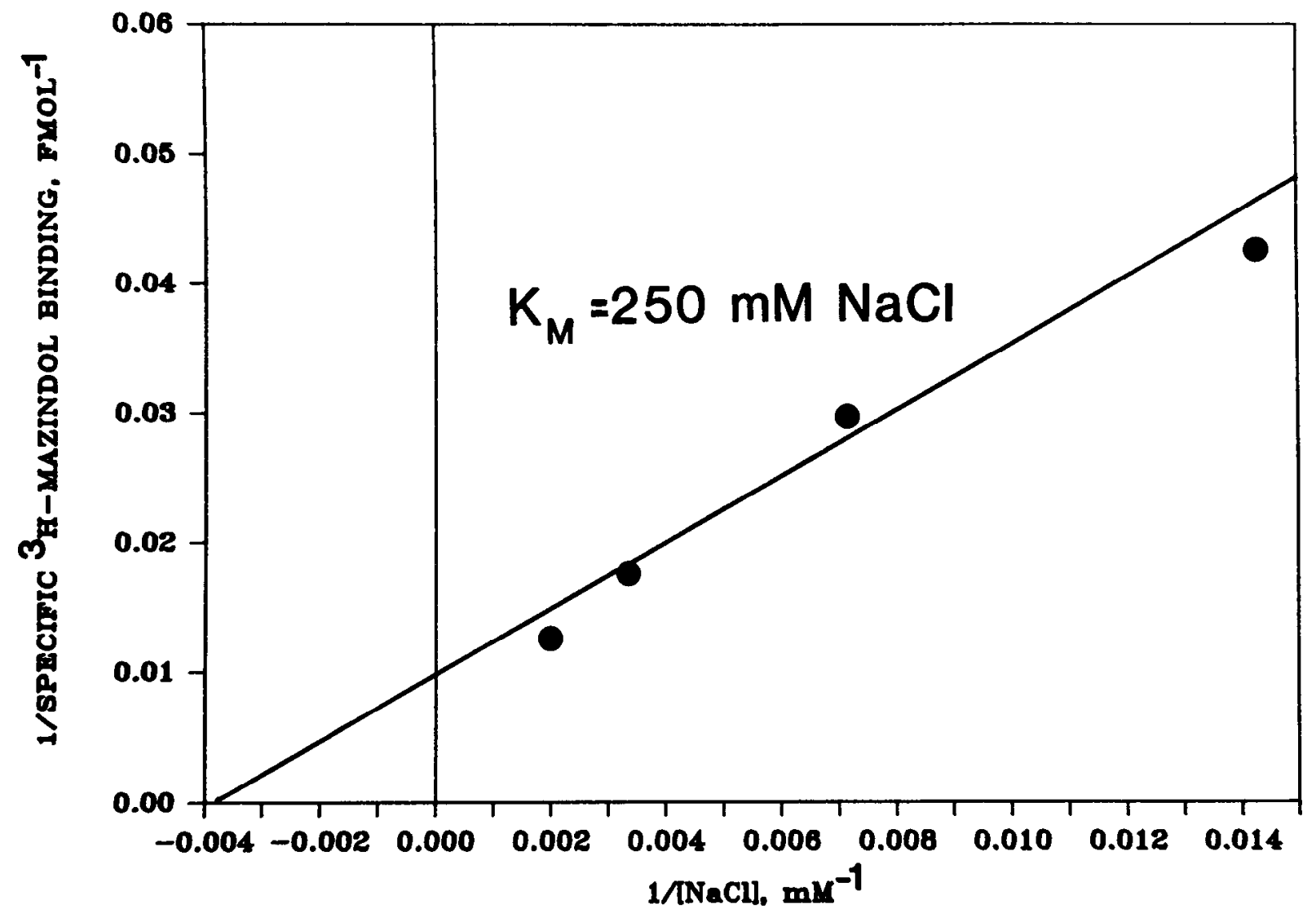

Figure 1. Effect of $\mathrm{NaCl}$ on specific $\left[{ }^{3} \mathrm{H}\right]$ mazindol binding to slices of rat caudate-putamen. Binding experiments were performed with $\left.4 \mathrm{nM} \mathrm{l}^{3} \mathrm{H}\right] \mathrm{mazindol}$ and $1 \mu \mathrm{M}$ unlabeled mazindol to define nonspecific binding. Sodium chloride concentration was varied from 0 to $500 \mathrm{~mm}$. No specific binding was seen in the absence of $\mathrm{NaCl}$ or in the presence of increasing concentrations of $\mathrm{KCl}$ up to $500 \mathrm{mM}$. Results are the mean of two separate determinations performed in duplicate. The line of best fit was determined by linear regression $(r=0.98)$. 
$B_{\max }$ of $150 \mathrm{fmol} / \mathrm{mg}$ of protein. Furthermore, $0.3 \mu \mathrm{M}$ DMI has a negligible effect on specific $\left[{ }^{3} \mathrm{H}\right]$ mazindol binding to DA uptake sites in striatal homogenates (Fig. 2) or striatal slices (Table I).

Autoradiographic localization of $\left[{ }^{3} \mathrm{H}\right]$ mazindol binding in rat brain. The distribution of specific $\left[{ }^{3} \mathrm{H}\right]$ mazindol binding sites in rat brain is summarized in Table II. DMl at $0.3 \mu \mathrm{M}$ is used to abolish selectively the noradrenergic component and $1 \mu \mathrm{M}$ unlabeled mazin-

TABLE ।

Effect of drugs on specific [ $\left.{ }^{3} \mathrm{H}\right]$ mazindol binding to rat corpus striatum $\left[{ }^{3} \mathrm{H}\right]$ Mazindol binding to tissue sections was assayed as described in "Materials and Methods" in the presence of $300 \mathrm{mM} \mathrm{NaCl}$ and the indicated concentration of inhibitors. Values are expressed as percentage of binding in the absence of inhibitor and are the means of two determinations performed in duplicale, which varied less than $15 \% . K_{i}$ values for the inhibition of $\left[{ }^{3} \mathrm{H}\right] \mathrm{DA}$ uptake into striatal synaptosomes and $\left[{ }^{3} \mathrm{H}\right]$ mazindol binding to striatal homogenates are from Javitch et al. (1984).

\begin{tabular}{|c|c|c|c|c|}
\hline \multirow[b]{2}{*}{ Drug } & \multirow[b]{2}{*}{$\begin{array}{c}\text { Concentration } \\
\text { of Inhibitor } \\
(\mu \mathrm{M})\end{array}$} & \multirow{2}{*}{$\begin{array}{c}\text { Percentage } \\
\text { of Total } \\
\text { Specific [ }{ }^{3} \mathrm{H} \text { ] } \\
\text { Mazindol } \\
\text { Binding to } \\
\text { Striatal } \\
\text { Slices }\end{array}$} & \multicolumn{2}{|c|}{$\mathrm{K}_{\mathrm{i}}$} \\
\hline & & & $\begin{array}{c}{\left[{ }^{3} \mathrm{H}\right] \mathrm{CA} \text { Uptake }} \\
\text { Striatal } \\
\text { Synaptosomes } \\
(\mu \mathrm{M})\end{array}$ & $\begin{array}{c}{\left[{ }^{3} \mathrm{H}\right] \mathrm{Mazindol}} \\
\text { Binding } \\
\text { Striatal } \\
\text { Homogenates } \\
(\mu \mathrm{M})\end{array}$ \\
\hline Mazindol & 0.02 & 53 & 0.016 & 0.023 \\
\hline Nomifensine & 0.10 & 44 & 0.043 & 0.084 \\
\hline Benztropine & 0.20 & 47 & 0.098 & 0.22 \\
\hline DMI & 0.30 & 94 & 8.1 & 12.2 \\
\hline
\end{tabular}

dol to block both NE and DA uptake sites (Fig. 2; see "Materials and Methods").

The densest localization of DMl-insensitive specific [ $\left.{ }^{3} \mathrm{H}\right]$ mazindol binding occurs in the caudate-putamen, the nucleus accumbens, and the olfactory tubercle (Figs. 3 and 4). In the caudate-putamen, specific binding is seen only in gray matter. Also densely labeled are the subthalamic nucleus, the ventral tegmental area (VTA), the SN, pars compacta (Fig. 5), and anterior olfactory nuclei. Substantial autoradiographic silver grains occur in the SN pars reticulata, the locus coeruleus, the nucleus of the solitary tract, the lateral habenula, the supraoptic and paraventricular nuclei of the hypothalamus, the amygdala, the dorsal raphe nucleus, the bed nucleus of the stria terminalis, and the median eminence. Low levels of DMl-insensitive specific $\left[{ }^{3} \mathrm{H}\right]$ mazindol binding are seen in the arcuate and periventricular nuclei of the hypothalamus, the thalamus, the mamillary complex, superficial layers of the cerebral cortex, the lateral septum, globus pallidus, and dentate gyrus.

The distribution of DMl-sensitive [ $\left.{ }^{3} \mathrm{H}\right]$ mazindol sites differs markedly from that observed for DMl-insensitive $\left[{ }^{3} \mathrm{H}\right]$ mazindol binding (Fig. 3). Thus, the highest density of DMI-sensitive $\left[{ }^{3} \mathrm{H}\right]$ mazindol binding occurs in the locus coeruleus and the nucleus of the solitary tract. High levels of binding are also detected in the paraventricular and periventricular nuclei of the hypothalamus, the bed nucleus of the stria terminalis, and the anteroventral nucleus of the thalamus. Substantial grain densities occur in the ventral medullary region, superficial layers of the cerebral cortex, the median eminence, the habenula, the lateral septum, the supraoptic nucleus, the amygdala, the dorsal raphe nucleus, the mamillary nucleus, the interpeduncular nucleus, the hippocampus and dentate gyrus, the zona incerta, and

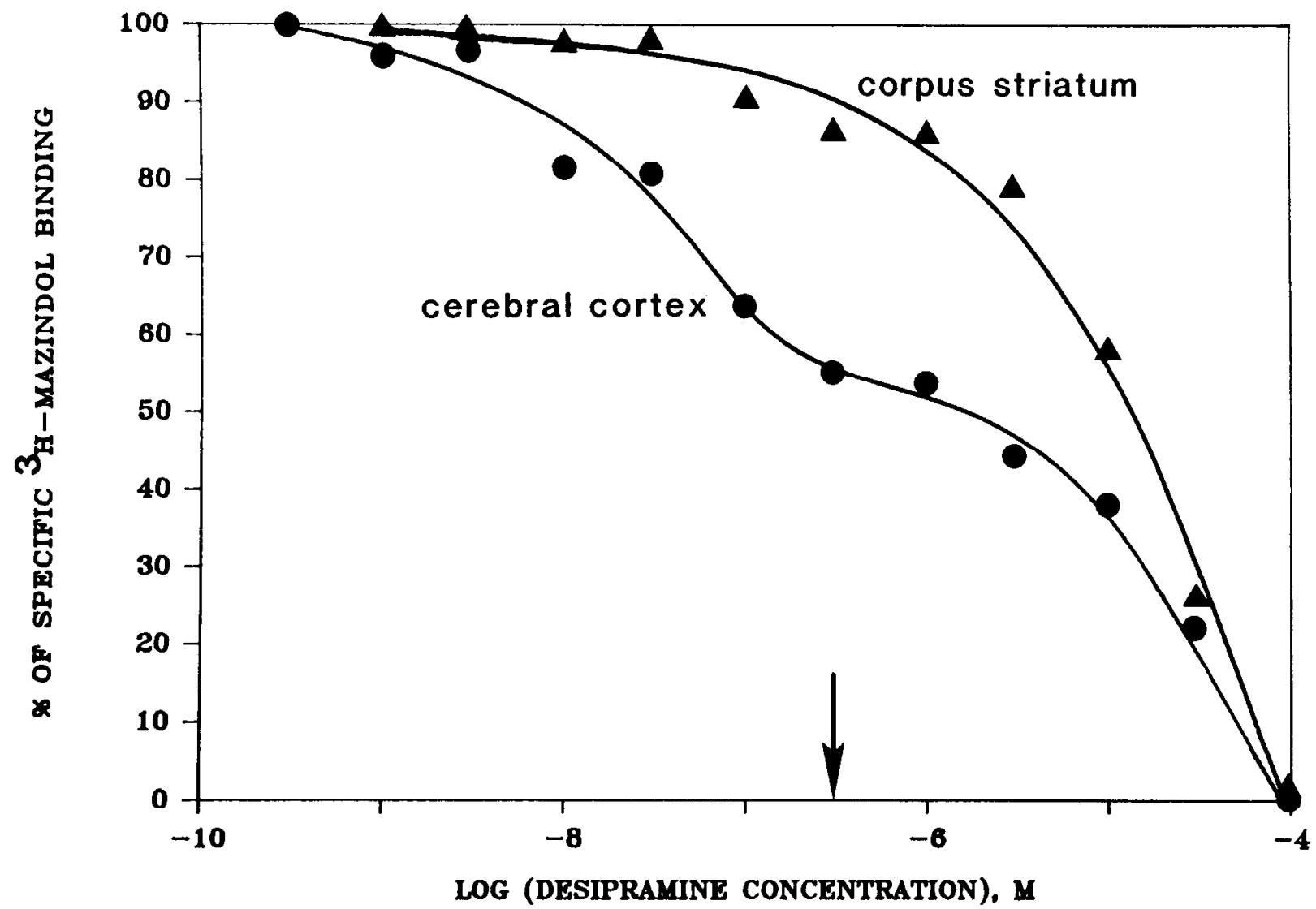

Figure 2. Inhibition of specific $\left[{ }^{3} \mathrm{H}\right]$ mazindol $(4 \mathrm{nM})$ binding by unlabeled DMl in rat cerebral cortical and striatal membranes. Specific binding was calculated by subtracting nonspecific binding in the presence of $100 \mu \mathrm{M} \mathrm{DMl} \mathrm{from} \mathrm{the} \mathrm{total} \mathrm{binding} \mathrm{and} \mathrm{is} \mathrm{expressed} \mathrm{as} \mathrm{a} \mathrm{percentage} \mathrm{of} \mathrm{binding} \mathrm{in} \mathrm{the}$ absence of unlabeled DMl. The arrow indicates $0.3 \mu \mathrm{M} \mathrm{DMl}$, the concentration used to inhibit the high-affinity component of binding to cortical membranes without substantially inhibiting the low affinity component of binding to cortical membranes or binding to striatal membranes. Results are the mean of two separate determinations performed in triplicate. 


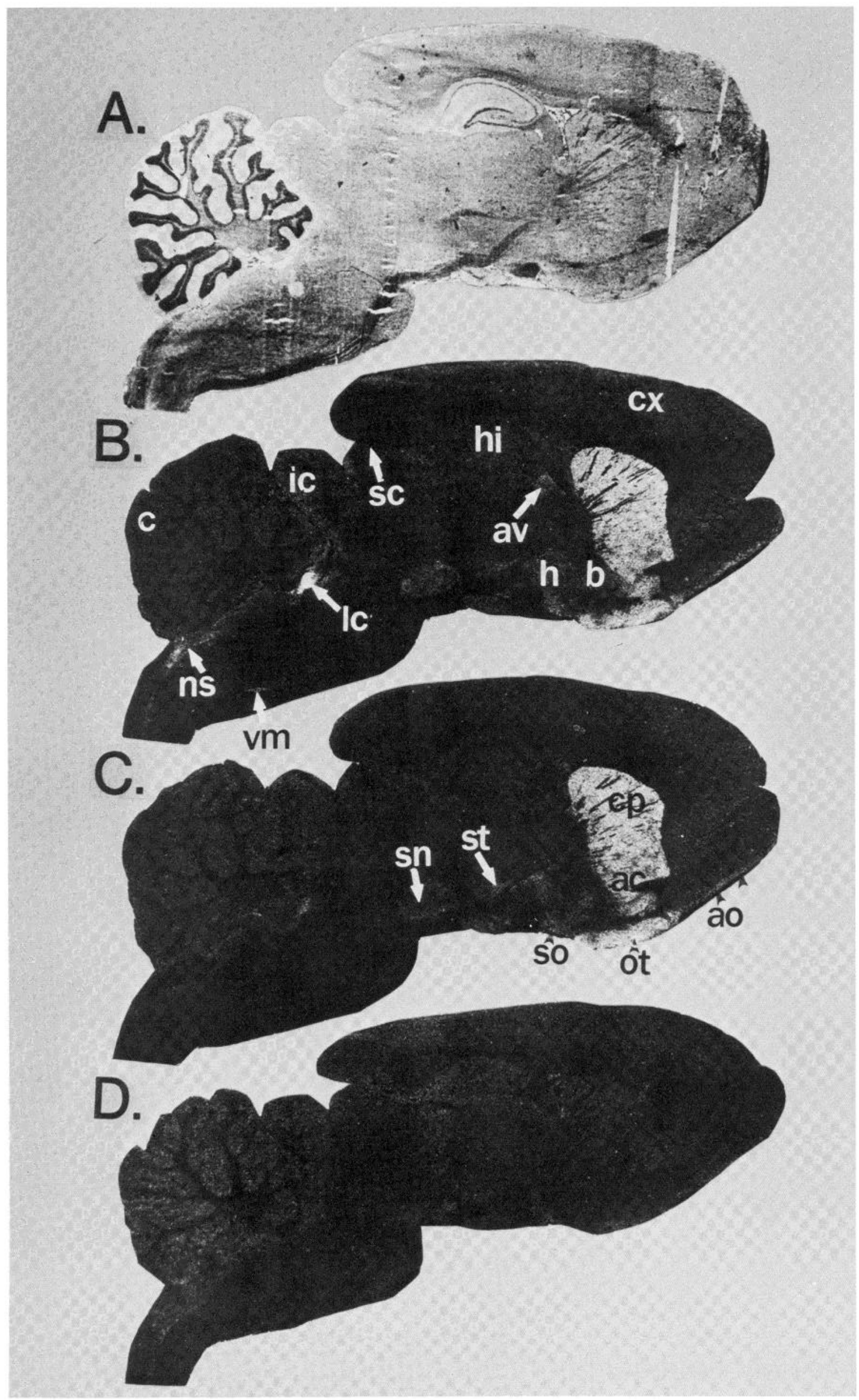

Figure 3. Autoradiograms of $\left[{ }^{3} \mathrm{H}\right]$ mazindol binding sites in sagittal sections of rat brain. $A$, Serial section stained with $0.1 \%$ toluidine blue. $B$, High levels of $\left[{ }^{3} \mathrm{H}\right]$ mazindol binding to NE uptake sites are seen in the locus coeruleus, the nucleus of the solitary tract, the ventral medullary region, and the anteroventral 
TABLE ॥

Regional localization of $\left.{ }^{3} \mathrm{H}\right]$ mazindol binding to $D A$ and NE uptake sites

${ }^{3} \mathrm{H} \mid$ Mazindol (4 $\mathrm{nM}$ ) binding to tissue sections was assayed as described in "Materials and Methods" in the presence of $300 \mathrm{mM} \mathrm{NaCl}$. Since the $K_{D}$ for $\left[{ }^{3} \mathrm{H}\right]$ mazindol binding to NE uptake sites is about $25 \%$ of its $K_{D}$ for DA uptake sites, the values presented represent roughly half the maximal number of NE uptake sites but only one-eighth the number of DA uptake sites. Binding levels in each region were determined using computer-assisted microdensitometry (Kuhar et al., 1984). Values represent the means of determinations in 2 to 5 areas in representative sections from each of two animals, which varied less than $20 \%$. Density is described on a scale from 0 to 5 where each level is defined as follows: 0,0 to $0.04 \mathrm{pmol} / \mathrm{mg}$ protein; $1,0.04$ to $0.2 \mathrm{pmol} / \mathrm{mg}$ protein; $2,0.2$ to $0.5 \mathrm{pmol} / \mathrm{mg}$ protein; $3,0.5$ to 0.9 $\mathrm{pmol} / \mathrm{mg}$ protein; $4,0.9$ to $1.5 \mathrm{pmol} / \mathrm{mg}$ protein; $5,1.5$ to $2 \mathrm{pmol} / \mathrm{mg}$ protein. Values for density of $\left[{ }^{3} \mathrm{H}\right] \mathrm{DMl}$ binding are from Biegon and Rainbow (1983).

\begin{tabular}{|c|c|c|c|}
\hline Brain Region & $\begin{array}{c}\text { DMl-insensitive } \\
{\left[{ }^{3} \mathrm{H}\right] \mathrm{Mazindol}} \\
\text { Binding to DA } \\
\text { Uptake Sites }\end{array}$ & $\begin{array}{c}\text { DMM-sensitive } \\
{\left[{ }^{3} \mathrm{H}\right] \text { Mazindol }} \\
\text { Binding to } \\
\text { NE Uptake } \\
\text { Sites }\end{array}$ & $\begin{array}{c}{\left[{ }^{3} \mathrm{H}\right] \mathrm{DM}} \\
\text { Binding to } \\
\text { NE Uptake } \\
\text { Sites }\end{array}$ \\
\hline Caudate-putamen & 5 & 1 & 1 \\
\hline Nucleus accumbens & 5 & 1 & 1 \\
\hline Olfactory tubercle & 5 & 1 & $N^{a}$ \\
\hline Subthalamic nucleus & 4 & 0 & ND \\
\hline VTA & 4 & 1 & ND \\
\hline Anterior olfactory nuclei & 3 & 2 & ND \\
\hline \multicolumn{4}{|l|}{ SN } \\
\hline Pars compacta & 3 & 0 & 0 \\
\hline Pars reliculata & 2 & 1 & ND \\
\hline Median eminence & 2 & 2 & ND \\
\hline Locus coeruleus & 2 & 5 & 3 \\
\hline $\begin{array}{l}\text { Nucleus tractus solita- } \\
\quad \text { rus }\end{array}$ & 2 & 4 & ND \\
\hline Lateral habenula & 2 & 2 & $\mathrm{ND}$ \\
\hline Supraoptic nucleus & 2 & 2 & 2 \\
\hline Paraventricular nucleus & 2 & 3 & 2 \\
\hline Amygdala & 2 & 2 & ND \\
\hline Dorsal raphe & 2 & 2 & 2 \\
\hline $\begin{array}{l}\text { Bed nucleus stria termi- } \\
\text { nalis }\end{array}$ & 2 & 3 & 3 \\
\hline Anteroventral thalamus & 1 & 3 & 3 \\
\hline Ventral thalamus & 1 & 1 & 1 \\
\hline Mamillary nucleus & 1 & 2 & 2 \\
\hline Frontal cortex & 1 & 2 & 1 \\
\hline Arcuate nucleus & 1 & 2 & 3 \\
\hline Periventricular nucleus & 1 & 3 & 2 \\
\hline Lateral septum & 1 & 2 & 1 \\
\hline Globus pallidus & 1 & 0 & 0 \\
\hline Dentate gyrus & 1 & 2 & 2 \\
\hline $\begin{array}{l}\text { Ventral medullary re- } \\
\text { gion }\end{array}$ & 0 & 2 & ND \\
\hline Hippocampus & 0 & 2 & 1 \\
\hline Interpeduncular nucleus & 0 & 2 & 2 \\
\hline Zona incerta & 0 & 2 & 2 \\
\hline Central gray & 0 & 2 & 2 \\
\hline Superior colliculus & 0 & 2 & 2 \\
\hline Interior colliculus & 0 & 1 & 1 \\
\hline Cerebellar cortex & 0 & 1 & 1 \\
\hline Medial habenula & 0 & 2 & ND \\
\hline Medial septum & 0 & 1 & 1 \\
\hline
\end{tabular}

${ }^{a} \mathrm{ND}$, not determined. the central gray matter. We observe lower levels of binding in the inferior colliculus, the medial septum, the cerebellar cortex, the ventral thalamus, the VTA, the caudate-putamen, the nucleus accumbens, and the olfactory tubercle.

Effects of lesions on [ $\left.{ }^{3} \mathrm{H}\right]$ mazindol binding to caudate-putamen. The most prominent density of $\left[{ }^{3} \mathrm{H}\right]$ mazindol binding throughoul the brain occurs in the caudate-putamen. To ascertain whether these binding sites occur on terminals of the nigrostriatal dopaminergic pathway, a series of lesions was performed. Ibotenic acid, colchicine, or 6-OH DA was stereotaxically injected unilaterally into the SN. Each of these injections elicits a profound reduction of $\left[{ }^{3} \mathrm{H}\right]$ mazindol binding in the ipsilateral caudate-putamen (Table IIf; Fig. 6). Injections of saline alone into the SN have no effect on $\left[{ }^{3} \mathrm{H}\right]$ mazindol binding to the ipsilateral caudate-putamen.

Unilateral injections of ibotenic acid into the caudate-putamen do not affect $\left[{ }^{3} \mathrm{H}\right]$ mazindol binding to the ipsilateral or contralateral caudate-putamen in adjacent sections from the same brains. These same lesions lower $\left[{ }^{3} \mathrm{H}\right]$ captopril binding to angiotensin-converting enzyme by 80 to $90 \%$ in the ipsilateral caudate-putamen, reflecting a localization of the enzyme to a striatonigral pathway (Strittmatter ct al., 1984).

\section{Discussion}

$\left[{ }^{3} \mathrm{H}\right]$ Mazindol labels both DA and NE uptake sites (Javitch et al., $1983 ; 1984)$. The $K_{D}$ and $B_{\max }$ values as well as drug potencies in blocking $\left[{ }^{3} \mathrm{H}\right]$ mazindol binding to brain slices agree with values obtained in brain homogenates (Javitch et al., 1983, 1984). Moreover, ionic requirements for binding to slices and homogenates are similar and resemble those for $\left[{ }^{3} \mathrm{H}\right] \mathrm{DA}$ accumulation into striatal synaptosomes (Holz and Coyle, 1979).

It is possible to separate the dopaminergic and noradrenergic components of $\left[{ }^{3} \mathrm{H}\right]$ mazindol binding using $0.3 \mu \mathrm{M}$ DMI, a concentration sufficient to abolish binding to NE uptake sites without significantly affecting binding to DA uptake sites (Javitch et al., 1984). The regional distribution of DMl-sensitive specific $\left[{ }^{3} \mathrm{H}\right]$ mazindol binding closely resembles the localization of noradrenergic cell bodies and terminal projections as demonstrated by dopamine $\beta$ hydroxylase immunohistochemistry and catecholamine histofluorescence (Fuxe, 1965; Ungerstedt, 1971; Hartman et al., 1972; Hartman, 1973; Swanson and Hartman, 1975; Moore and Bloom, 1979; Biegon and Rainbow, 1983; Lindvall and Bjorklund, 1983). In contrast, the DMl-insensitive component of specific $\left[{ }^{3} \mathrm{H}\right]$ mazindol binding parallels the distribution of dopaminergic neurons and their projections (Fuxe, 1965; Moore and Bloom, 1978; Lindvall and Bjorklund, 1983).

The high levels of DMl-insensitive specific $\left[{ }^{3} \mathrm{H}\right]$ mazindol binding to caudate-putamen, nucleus accumbens, and olfactory tubercle are to uptake sites on the terminals of DA neurons originating in the SN and VTA. This conclusion is supported by the success of colchicine, ibotenic acid (Schwarcz et al., 1979), or 6-OHDA (Breese and Traylor, 1979) lesions of the SN/VTA region to profoundly decrease DMl-insensitive specific $\left[{ }^{3} \mathrm{H}\right]$ mazindol binding to the ipsilateral caudate-putamen.

High levels of DMI-insensitive specific $\left[{ }^{3} \mathrm{H}\right]$ mazindol binding are seen in the subthalamic nucleus, which contains moderate levels of DA (Versteeg et al., 1976) and catecholamine fibers (Brown et al., 1979; Meibach and Katzman, 1979). [ $\left.{ }^{3} \mathrm{H}\right]$ Mazindol binding to the SN pars reticulata reflects the substantial levels of DA uptake into dendrites of this region (Geffen et al., 1976). High levels of $\left[{ }^{3} \mathrm{H}\right]$ mazindol binding to DA uptake sites occur in the SN pars compacta and VTA, the origins of the mesotelencephalic dopaminergic system.

thalamus. $C,\left[{ }^{3} \mathrm{H}\right]$ Mazindol binding in the presence of $0.3 \mu \mathrm{M} \mathrm{DMl}$ to inhibit binding to NE uptake sites. High levels of binding to DA uptake sites are seen in the caudate-putamen, the nucleus accumbens, the olfactory tubercle, the subthalamic nucleus, and the SN, pars compacta. $D$, $\left[{ }^{3} \mathrm{H}\right] \mathrm{Mazindol}$ binding in the presence of $1 \mu \mathrm{M}$ unlabeled mazindol to inhibit binding to NE and DA uptake sites. $\left.{ }^{3} \mathrm{H}\right] \mathrm{Mazindol}(4 \mathrm{nM})$ autoradiography was performed in the presence of $300 \mathrm{~mm} \mathrm{NaCl} . a c$, nucleus accumbens; ao, anterior olfactory nuclei; $a v$, anteroventral thalamus; $b$, bed nucleus of the stria terminalis; $c$, cerebellum; $c p$, caudate-putamen; $c x$, cerebral cortex; $h$, hypothalamic regions; $h i$, hippocampus; ic, interior colliculus; $/ c$, locus coeruleus; $n s$, nucleus of the solitary tract; ot, olfactory tubercle; sc, superior colliculus; $s n$, substantia nigra; so, supraoptic nucleus; st, subthalamic nucleus; $v m$, ventral medullary region. 


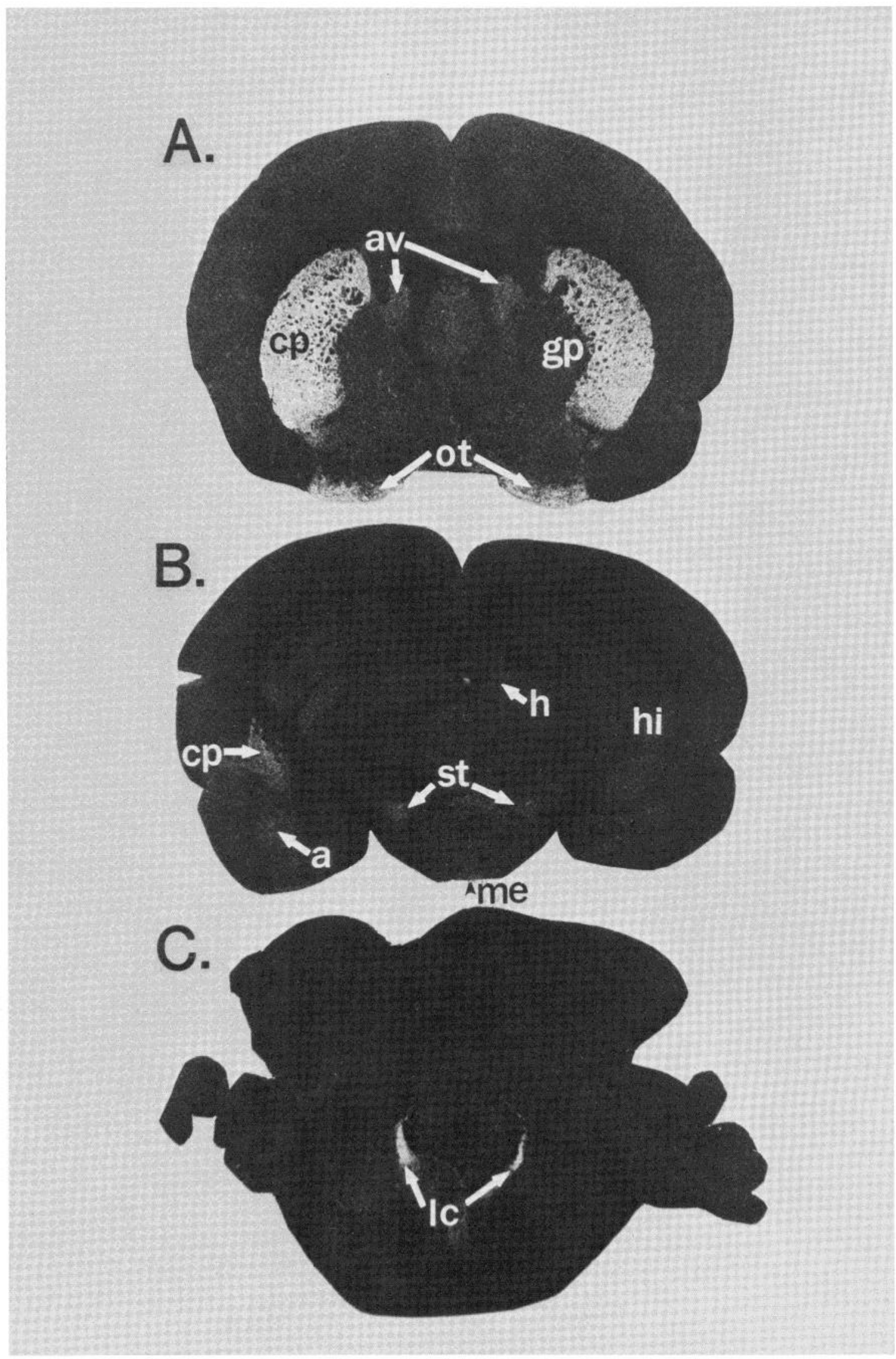

Figure 4. Autoradiogram of $\left[{ }^{3} \mathrm{H}\right]$ mazindol binding sites in coronal sections of rat brain. A, High levels of binding are seen in the caudate-putamen, the olfactory tubercle, and the anteroventral thalamus. $B$, High levels of binding are seen in the subthalamic nuclei and the caudate-putamen. $C$, Intense binding is seen in the locus coeruleus. [ ${ }^{3} \mathrm{H}$ ] Mazindol $(4 \mathrm{nM})$ autoradiography was performed in the presence of $300 \mathrm{~mm} \mathrm{NaCl}$. $a$, amygdala; av, anteroventral thalamus; $c p$, caudate-putamen; $g p$, globus pallidus; $h$, habenula; $h i$, hippocampus; $l c$, locus coeruleus; me, median eminence; ot, olfactory tubercle; st, subthalamic nucleus. 

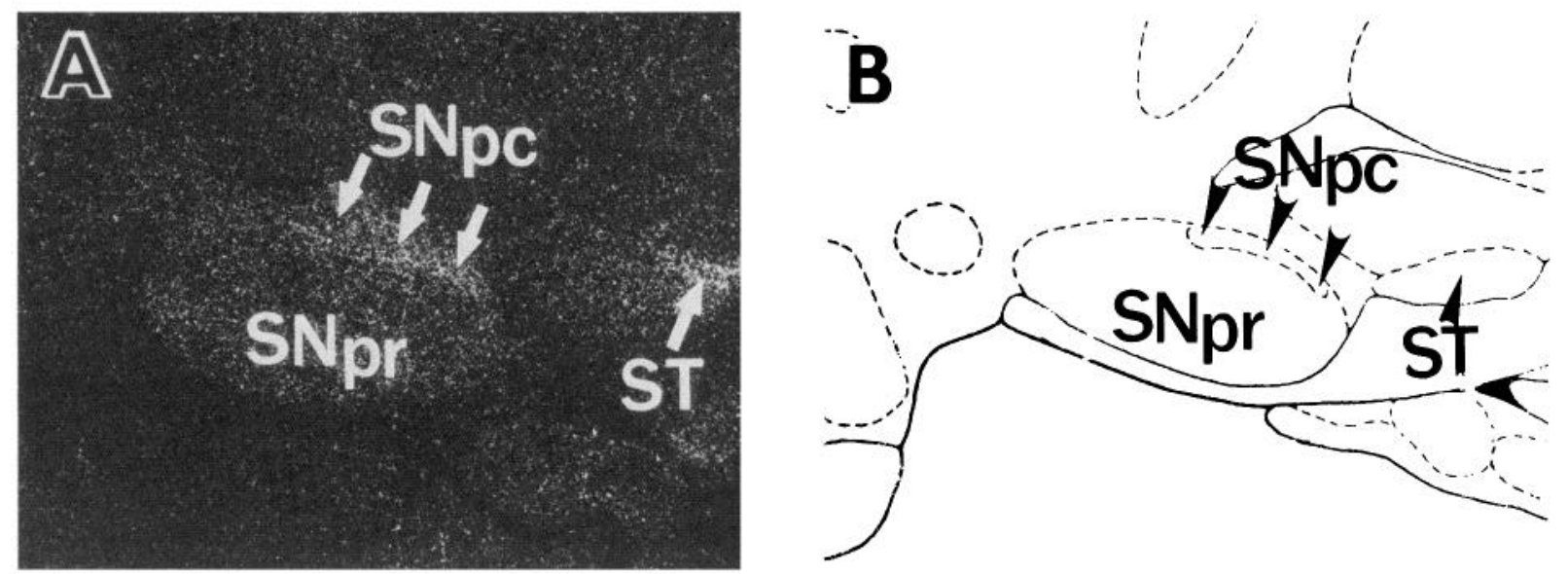

Figure 5. Autoradiogram of $\left[{ }^{3} \mathrm{H}\right]$ mazindol binding sites in a sagittal section at the level of the substantia nigra and subthalamic nucleus of the rat brain. $A$, High levels of binding are seen in the substantia nigra, pars compacta, and the subthalamic nucleus. Moderate binding is seen in the substantia nigra, pars reticulata. $B$, Schematic representation of tissue section from $A$, adapted from the data of Paxinos and Watson (1982). [ $\left.{ }^{3} \mathrm{H}\right] \mathrm{Mazindol}$ autoradiography $(4 \mathrm{nM})$ was performed in the presence of $300 \mathrm{~mm} \mathrm{NaCl}$. SNpc, substantia nigra, pars compacta; SNpr, substantia nigra, pars reticulata; ST, subthalamic nucleus.

\section{TABLE III}

Effect of lesions on $\left[{ }^{3} \mathrm{H}\right]$ mazindol binding

$\left[{ }^{3} \mathrm{H}\right]$ Mazindol $(4 \mathrm{nM})$ binding to tissue sections was performed as described in "Materials and Methods" in the presence of $120 \mathrm{~mm} \mathrm{NaCl}$. Lesions were performed as described in "Materials and Methods." Binding levels were determined using computer-assisted microdensitometry (Kuhar et al., 1984).

\begin{tabular}{llc}
\hline \multirow{2}{*}{ Treatment } & \multicolumn{2}{c}{$\begin{array}{c}\text { [ } \mathrm{H}] \text { Mazindol binding (fmol/mg of } \\
\text { protein) in Caudate-Putamen }\end{array}$} \\
\cline { 2 - 3 } & Control side & Lesion side \\
\hline SN lesions & & \\
Ibotenic acid $(n=3)$ & $440 \pm 80^{a}$ & $60 \pm 30^{b}(14 \%)^{c}$ \\
Colchicine $(n=3)$ & $550 \pm 150$ & $90 \pm 80^{\circ}(16 \%)$ \\
6-OHDA $(n=1)$ & 560 & $100(18 \%)$ \\
Saline-control $(n=1)$ & 450 & $430(96 \%)$ \\
Caudate-putamen le- & & \\
$\quad$ sions & & \\
Ibotenic acid $(n=3)$ & $490 \pm 50$ & $480 \pm 100(98 \%)$ \\
\hline
\end{tabular}

${ }^{a}$ Mean $\pm \mathrm{SE}$.

${ }^{b} p<0.005$ compared to control side.

${ }^{c}$ Numbers in parentheses, percentage of binding on the lesion side relative to the control side.

While DA concentrations in these regions are only 10 to $20 \%$ of those in the caudate-putamen, specific $\left[{ }^{3} \mathrm{H}\right]$ mazindol binding to DA uptake sites in these cell body containing areas is 30 to $50 \%$ of that in the caudate-putamen. This finding fits with studies showing a higher ratio of DA uptake to endogenous DA concentration in cell body areas than in terminal areas (Geffen et al., 1976; Beart et al., 1979; Beart and McDonald, 1980). Proportionally higher amine uptake in cell bodies than in terminals may reflect ongoing synthesis of uptake sites at the rough endoplasmic reticulum of the cell body prior to their transport to terminal areas. Transmitter presumably accumulates primarily in mature secretory granules of terminals.

While comparable concentrations of DA are found in the caudateputamen and median eminence, the ratio of $\left[{ }^{3} \mathrm{H}\right]$ mazindol binding to DA uptake is 10 times higher in caudate-putamen, agreeing with the proportionally lower $\left[{ }^{3} \mathrm{H}\right] \mathrm{DA}$ uptake into synaptosomes prepared from median eminence (Cuello et al., 1973; Cuello and Iversen, 1973; Demarest and Moore, 1979). As DA is released from tuberohypophyseal dopaminergic neurons into the portal blood vessels, there may be less need to inactivate synaptic levels of transmitter via reuptake. Fewer uptake sites may explain the difficulty in destroying DA cells in the tuberohypophyseal system with 6-OHDA (Cuello et al., 1974). The low level of [ $\left.{ }^{3} \mathrm{H}\right]$ mazindol binding to DA uptake sites in the median eminence is paralleled by similar low levels in the arcuate nucleus, the site of origin of the tuberohypophyseal system.

Other regions with substantial DMl-insensitive specific $\left[{ }^{3} \mathrm{H}\right]$ mazindol binding correlate with the projection of DA neurons. The lateral habenula contains a dense collection of catecholaminergic axons, as well as substantial DA concentrations (Lindvall and Bjorklund, 1983; Versteeg et al., 1976). Tyrosine hydroxylase immunohistochemistry has also demonstrated a catecholaminergic fiber system in this location (Lindvall and Bjorklund, 1983). Furthermore, DMIinsensitive DA uptake has been measured in the lateral habenula (Lindvall and Bjorklund, 1983).

The lateral septal nucleus is innervated by a dopaminergic projection from the VTA as is the bed nucleus of the stria terminalis (Moore and Bloom, 1978; Lindvall and Bjorklund, 1983). There is also a dopaminergic innervation of the amygdala originating in the VTA and medial SN (Lindvall and Bjorklund, 1983). Binding to DA uptake sites in hypothalamic regions, the thalamus, and septum is probably associated with the periventricular and incertohypothalamic DA systems (Lindvall and Bjorklund, 1983). DMl-insensitive $\left[{ }^{3} \mathrm{H}\right]$ mazindol binding to locus coeruleus presumably reflects uptake sites on the terminals of dopaminergic neurons in the mesopontine system (Lindvall and Bjorklund, 1983). Cerebral cortical areas are innervated by the mesocortical dopaminergic system (Moore and Bloom, 1978; Lindvall and Bjorklund, 1983), explaining DMl-insensitive $\left[{ }^{3} \mathrm{H}\right]$ mazindol binding to cerebral cortex. The anterior olfactory nuclei are also innervated by a projection from the medial SN and VTA (Lindvall and Bjorklund, 1983).

DMl-sensitive specific $\left[{ }^{3} \mathrm{H}\right]$ mazindol binding is densest in the locus coeruleus, the site of origin of many noradrenergic neurons (Moore and Bloom, 1979; Lindvall and Bjorklund, 1983). The very high levels of binding to NE uptake sites in this cell body area may reflect the same sort of factors that operate in DA cell body areas. The high densities of binding in the nucleus of the solitary tract also may be associated with catecholamine cell bodies.

Although catecholaminergic systems have been visualized by tyrosine hydroxylase and dopamine $\beta$-hydroxylase immunohistochemistry and catecholamine histofluorescence, $\left[{ }^{3} \mathrm{H}\right]$ mazindol autoradiography provides several advantages over these techniques. Autoradiography independently and quantifiably labels both norepinephrine and dopamine uptake systems. Furthermore, the concerted 
Figure 6. Autoradiograms of $\left[{ }^{3} \mathrm{H}\right]$ mazindol binding sites in coronal sections of rat brain at the level of the caudate-putamen following unilateral lesions of the right $\mathrm{SN}$. $A$, Unilateral 6-OHDA lesion of the SN. B, Unilateral ibotenic acid lesion of the $\mathrm{SN}$. See the legend of Table III for experimental details.

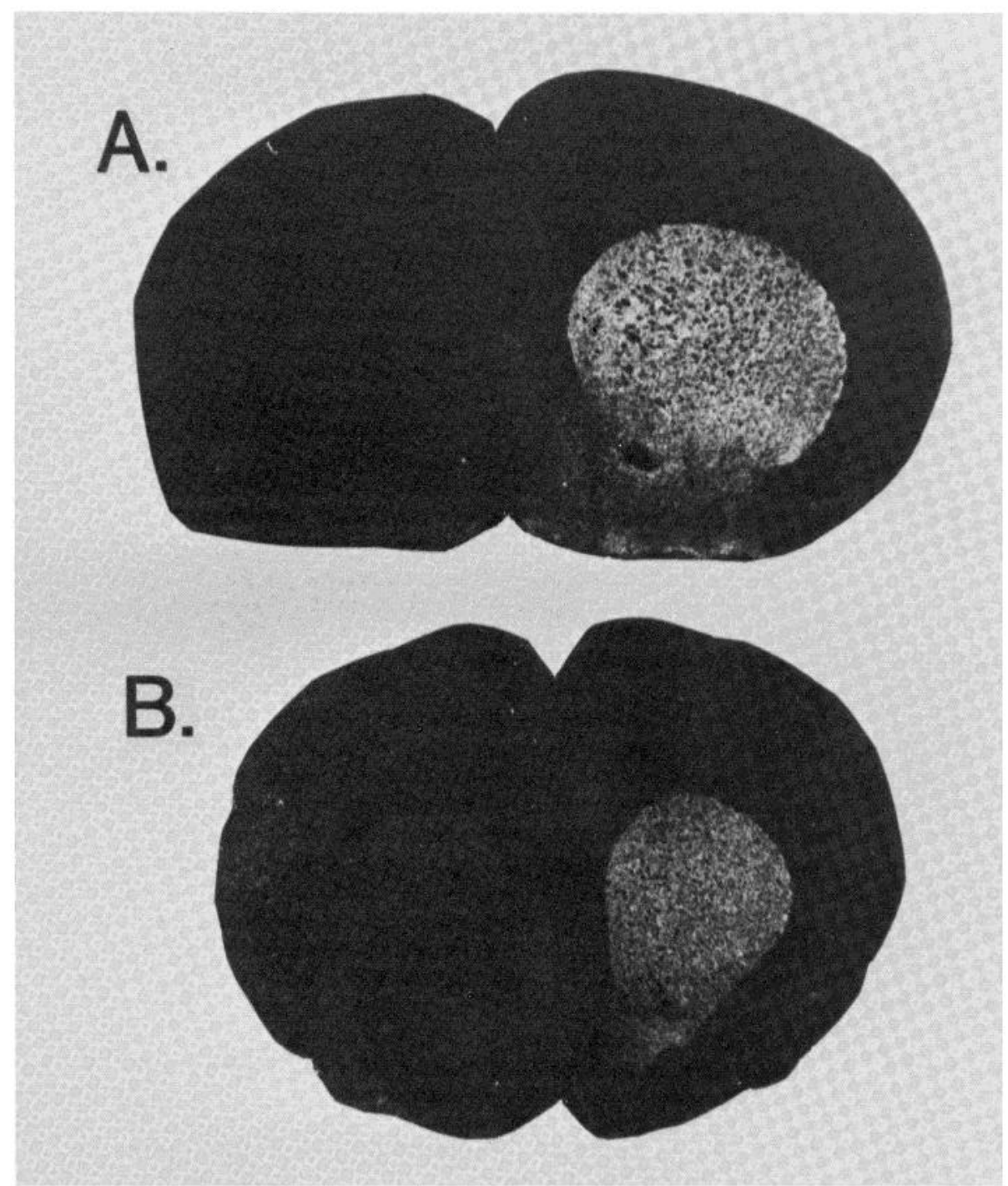

use of these three methods in adjacent sections would visualize the synthetic capability, transmitter levels, and transmitter inactivation potential of catecholaminergic neurons and projections.

Specific $\left[{ }^{3} \mathrm{H}\right]$ mazindol binding to both DA and NE uptake sites is stable in frozen tissue. Thus, $\left[{ }^{3} \mathrm{H}\right]$ mazindol autoradiography may be useful in studying changes in the catecholaminergic systems in clinical syndromes. Sodium-sensitive $\left[{ }^{3} \mathrm{H}\right]$ cocaine binding to striatal homogenates declines in patients with Parkinson's Disease (Pimoule et al., 1983). Using $\left[{ }^{3} \mathrm{H}\right]$ mazindol autoradiography, it would be possible to study the pattern of degeneration of dopaminergic terminals in Parkinson's Disease and other disease states.

\section{References}

Beart, P. M., and D. McDonald (1980) Neurochemical studies of the mesolimbic dopaminergic pathway: Somatodendritic mechanisms and GABAergic neurons in the rat ventral tegmentum. J. Neurochem. 34: 1622-1629.

Beart, P. M., D. McDonald, and A. L. Gundlach (1979) Mesolimbic dopaminergic neurons and somatodendritic mechanisms. Neurosci. Lett. 14. $165-170$.

Biegon, A., and T. C. Rainbow (1983) Localization and characterization of $\left[{ }^{3} \mathrm{H}\right]$ desmethylimipramine binding sites in rat brain by quantitative autoradiography. J. Neurosci. 3: 1069-1076.

Breese, G. R., and T. D. Traylor (1971) Depletion of brain noradrenaline and dopamine by 6-hydroxydopamine. Br. J. Pharmacol. 42: 88-99.

Brown, L. L., M. H. Makman, L. I. Wolfson, B. Dvorkin, C. Warner, and R. Katzman (1979) A direct role of dopamine in the rat subthalamic nucleus and an adjacent interpeduncular area. Science 206: 1416-1418.
Cuello, A. C., and L. L. Iversen (1973) Localization of tritiated dopamine in the median eminence of the rat hypothalamus by electron microscope autoradiography. Brain Res. 63: 474-478.

Cuello, A. C., A. S. Horn, A. V. P. Mackay, and L. L. Iversen (1973) Catecholamines in the median eminence: New evidence for a major noradrenergic input. Nature 243: 465-467.

Cuello, A. C., W. J. Shoemaker, and W. F. Ganong (1974) Effect of 6hydroxydopamine on hypothalamic norepinephrine and dopamine content, ultrastructure of the median eminence, and plasma cortiosterone. Brain Res. 78: 57-69.

Demarest, K. T., and K. E. Moore (1979) Lack of a high affinity transport system for dopamine in the median eminence and posterior pituitary. Brain Res. 171: 545-551.

Eckhardt, S. B., R. A. Maxwell, and R. M. Ferris (1982) A structure-activity study of the transport sites for the hypothalamic and striatal catecholamine uptake systems: Similarities and differences. Mol. Pharmacol. 21: 374379.

Fuxe, K. (1965) Evidence for the existence of monoamine neurons in the central nervous system. IV. Distribution of monoamine terminals in the central nervous system. Acta Physiol. Scand., 64 (Suppl. 247): 39-85.

Geffen, L. B., T. M. Jessell, A. C. Cuello, and L. L. Iversen (1976) Release of dopamine from dendrites in rat substantia nigra. Nature 260: 258-260.

Hartman, B. K. (1973) Immunofluorescence of dopamine $\beta$-hydroxylase: Application of improved methodology to the localization of the peripheral and central noradrenergic nervous system. J. Histochem. Cytochem. 21: 312-332.

Hartman, B. K., D. Zide, and S. Udenfriend (1972) The use of dopamine $\beta$ hydroxylase as a marker for the central noradrenergic nervous system in rat brain. Proc. Natl. Acad. Sci. U. S. A. 69: 2722-2726. 
Hcikkila, R. E., F. S. Cabbat, and C. Mytilineou (1977) Studies of the capacity of mazindol and DITA to act as uptake inhibitors or releasing agents for ${ }^{3} \mathrm{H}$-biogenic amines in rat brain tissue slices. Eur. J. Pharmacol. 45: 329333.

Holz, R. W., and J. T. Coyle (1979) The effects of various salts, temperature, and the alkaloids veratridine and batrachotoxin on the uptake of $\left[{ }^{3} \mathrm{H}\right]$ dopamine into synaptosomes from rat striatum. Mol. Pharmacol. 10: 746758.

Horn, A. S. (1973) Structure-activity relations for the inhibition of catecholamine uptake into synaptosomes from noradrenaline and dopaminergic neurones in rat brain homogenates. Br. J. Pharmacol. 47: 332-338.

Horn, A. S. (1976) Characteristics of transport in dopaminergic neurons. In The Mechanism of Neuronal and Extraneuronal Transport of Catecholamines, D. M. Paton, ed., pp. 195-214. Raven Press, New York.

Horn, A. S., J. T. Coyle, and S. H. Snyder (1971) Catecholamine uptake by synaptosomes from rat brain: Structure-activity relationships of drugs with differential effects on dopamine and norepinephrine neurons. Mol. Pharamcol. 7: 66-80.

Hrdina, P. D., K. Elson-Harman, D. C. S. Roberts, and B. A. Pappas (1981) High affinity $\left[{ }^{3} \mathrm{H}\right]$ desipramine binding in rat cerebral cortex decreases after selective lesions of noradrenergic neurons with 6-hydroxydopamine. Eur. J. Pharmcol. 73: 373-376.

Hyttel, J. (1982) Citalopram-pharmacological profile of a specific serotonin uptake inhibitor with antidepressant activity. Prog. Neuropsychopharmacol. Biol. Psychiatry 6: 277-295.

Javitch, J. A., R. O. Blaustein, and S. H. Snyder (1983) $\left[{ }^{3} \mathrm{H}\right]$ Mazindol binding associated with neuronal dopamine uptake sites in corpus striatum membranes. Eur. J. Pharmacol. 90: 461-462.

Javitch, J. A., R. O. Blaustein, and S. H. Snyder (1984) $\left[{ }^{3} \mathrm{H}\right]$ Mazindol binding associated with neuronal dopamine and norepinephrine uptake sites. Mol. Pharmacol. 26: 35-44

Kennedy, L. T., and I. Hanbauer (1983) Sodium-sensitive cocaine binding to rat striatal membranes: Possible relationship to dopamine uptake sites. J. Neurochem. 41: 172-178.

Kuhar, M. J., P. J. Whitehouse, J. R. Unnerstall, and H. Loats (1984) Receptor autoradiography: Analysis using a PC-based imaging system. Soc. Neurosci. Abstr. 10: 558.

Langer, S. Z., R. Raisman, and M. Briley (1981) High affinity [ ${ }^{3}$ H]DMl binding is associated with neuronal noradrenaline uptake in the periphery and the central nervous system. Eur. J. Pharmacol. 72: 423-424.

Lee, C. -M., and S. H. Snyder (1981) Norepinephrine neuronal uptake binding sites in rat brain membranes labeled with $\left[{ }^{3} \mathrm{H}\right]$ desipramine. Proc. Natl. Acad. Sci. U. S. A. 78: 5250-5254

Lee, C. -M., J. A. Javitch, and S. H. Snyder (1982) Characterization of $\left[{ }^{3} \mathrm{H}\right]$ desipramine binding associated with neuronal norepinephrine uptake sites in rat brain membranes. J. Neurosci. 2: 1515-1525.

Lee, C. -M., J. A. Javitch, and S. H. Snyder (1983) Norepinephrine uptake recognition sitcs labclcd by $\left[{ }^{3} \mathrm{H}\right]$ desipramine: Regulation by neurotransmitters. Science 220: 626-629.

Lindvall, O., and A. Bjorklund (1983) Dopamine- and norepinephrine-containing neuron systems: Their anatorny in the rat brain. In Chemical Neuroanatomy, P. C. Emson, ed., pp. 229-255, Raven Press, New York.

McPherson, G. A. (1983) A practical computer based approach to the analysis of radioligand binding studies. Comput. Programs Biomed. 17: $107-114$.

Meibach, R. C., and R. Katzman (1979) Catecholaminergic innervation of the subthalamic nucleus: Evidence for a rostral continuation of the $A 9$ (substantia nigra) dopaminergic cell group. Brain Res. 173: 364-368

Moore, R. Y., and F. E. Bloom (1978) Central catecholamine neuron systems: Anatomy and physiology of the dopamine system. Annu. Rev. Neurosci. 1: $129-169$.

Moore, R. Y., and F. E. Bloom (1979) Central catecholamine neuron systems: Anatomy and physiology of the norepinephrine and epinephrine systems. Annu. Rev. Neurosci. 2: 113-168.

Paxinos, G., and C. Watson (1982) The Rat Brain in Stereotaxic Coordinates, Academic Press, Inc., New York.

Pimoule, C., M. Schoemaker, F. Javoy-Agid, B. Scatton, Y. Agid, and S. Z. Langer (1983) Decrease in $\left[{ }^{3} \mathrm{H}\right]$ cocaine binding to the dopamine transporter in Parkinson's disease. Eur. J. Pharmacol. 95: 145-146.

Rehavi, M., P. Skolnick, M. J. Brownstein, and S. M. Paul (1982) High-affinity binding of $\left[{ }^{3} \mathrm{H}\right]$ desipramine to rat brain: A presynaptic marker for norad renergic uptake sites. J. Neurochem. 38: 889-895.

Ross, S. B. (1976) Structural requirements for uptake into catecholamine neurons. In The Mechanism of Neuronal and Extraneuronal Transport of Catecholamines, D. M. Paton, ed., pp. 67-93, Raven Press, New York.

Schwarcz, R., T. Hokfelt, K. Fuxe, G. Johnsson, M. Goldstein, and L. Terenius (1979) Ibotenic acid-induced neuronal degeneration: A morphological and neurochemical study. Exp. Brain Res. 37: 199-216.

Strittmatter, S. M., M. M. S. Lo, J. A. Javitch, and S. H. Snyder (1984) Autoradiographic visualization of angiotensin-converting enzyme in rat brain with $\left[{ }^{3} \mathrm{H}\right]$ captopril: Localization to a striatonigral pathway. Proc. Nath. Acad. Sci. U. S. A. 81: 1599-1603.

Swanson, L. W., and B. K. Hartman (1975) The central adrenergic system: An immunofluorescence study of the location of cell bodies and thei efferent connections in the rat utilizing dopamine $\beta$-hydroxylase as a marker. J. Comp. Neurol. 163: 467-506.

Ungerstedt, U. (1971) Stereotaxic mapping of the monoamine pathways in the rat brain. Acta Physiol. Scand., 367 (Suppl.): 1-48.

Unnerstall, J. R., D. L. Niehoff, M. J. Kuhar, and J. M. Palacios (1982) Quantitative receptor autoradiography using $\left[{ }^{3} \mathrm{H}\right]$ ultrofilm: Application to multiple benzodiazepine receptors. J. Neurosci. Methods 6: 59-73.

Versteeg, D. H. G., J. Van Der Gugten, W. De Jong, and M. Palkovits (1976) Regional concentrations of noradrenaline and dopamine in rat brain. Brain Res. 113; 563-574. 